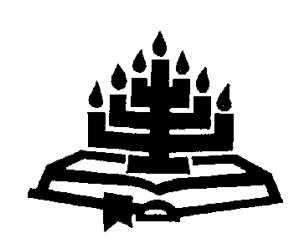

\title{
Aspekte van emosionele intelligensie in die lewe van die nuwe mens
}

\author{
C.J.H. Venter \\ Skool vir Kerkwetenskappe \\ Potchefstroomkampus \\ Noordwes-Universiteit \\ POTCHEFSTROOM
}

E-pos: kwscjhv@puknet.puk.ac.za

\begin{abstract}
Aspects of emotional intelligence in man - "made new"

Since the late nineties of the previous century research on emotional intelligence has received new impetus, mainly due to the work of Goleman in this field. This article focuses on emotional intelligence, especially from two points of view. Firstly, perspectives from Ephesians 4:20-24 are taken as point of departure to ascertain what is implied by "making new", i.e the way of life and conduct of someone made new in mind and spirit. The way in which a person's way of thinking is directed receives special attention as perceptions and feelings originate from the way in which one thinks and reflects on matters and situations. The command to discard old and sinful habits and to attire oneself with a new way of life plays a central role in the process of being made new in mind and spirit. Special attention is given to intercommunicative behaviour and the management of anger. In the second instance, the practical application of certain core aspects of emotional intelligence in the life of someone "made new" in spirit and mind is considered. A selection of definitions and models of research is touched upon and the following aspects typical of emotional intelligence are highlighted: self-awareness, awareness of one's own feelings and those of others, as well as the effective controlling of emotions. The way in which emotions originate and are embedded in one's way of thinking is highlighted, and ways of thinking to change the direction of emotions are suggested. Lastly certain practice-theoretical recommendations from a pastoral angle are made for those renewed in mind and spirit: a life "made new" should also reflect the acquisition of a new way of conduct, especially in applying ways of communicative behaviour and the practical management of anger.
\end{abstract}


Opsomming

Aspekte van emosionele intelligensie in die lewe van die nuwe mens

Sedert die laaste jare van die vorige eeu het wetenskaplike besinning oor emosionele intelligensie weer sterk na vore gekom - hoofsaaklik as gevolg van die werk van Goleman in hierdie verband. Hierdie artikel ondersoek emosionele intelligensie in die lewe van die nuwe mens. Eerstens word gegewens uit Efesiërs 4:20-24 oor die nuwe mens nagegaan om te bepaal wat geïmpliseer word deur die "nuutmaking" van die mens, veral dan die leef- en gedragswyse van die nuwe mens. Die wyse waarop iemand se manier van denke gerig word, ontvang spesiale aandag, omdat persepsies en gevoelens ontstaan op grond van die manier waarop iemand se denke gestruktureer word. Veral die wyse van denke van die nuwe mens word dus nagegaan, asook die opdrag om die ou mens "uit te trek" en die nuwe mens "aan te trek". Besondere aandag word gewy aan die kommunikasie van die nuwe mens en sy hantering van woede. Daarna word, vanuit die studieveld van emosionele intelligensie, gefokus op 'n seleksie definisies van en modelle vir die bestudering van emosionele intelligensie. Aspekte eie aan emosionele intelligensie, soos selfbewussyn, bewustheid van eie emosies en insig in die emosies van ander word betrek, asook hoe dié emosies prakties hanteer kan word in die lewe van die nuwe mens. Ook die ontstaan van emosies vanuit die denke word belig en maniere van dink om emosies te verander, word voorgestel. Laastens word op praktykteoretiese vlak aandag gewy aan die pastorale benaderingshoek, aan begeleiding in die wyse van denke, aan sosiale vaardighede en aan die aanleer van veranderde gedrag in die lewe van die nuwe mens, veral ten opsigte van kommunikasie en die praktiese hantering van woede.

\section{Oriëntering}

In hierdie artikel word gepoog om twee navorsingsterreine nader te ontgin met die oog op prakties-teologiese teorievorming. Die eerste gedeelte sal toepaslike gegewens verken oor die lewe van die nuwe mens, veral soos dit in Efesiërs na vore kom. Ander verbandhoudende gedeeltes uit die Nuwe Testament sal ook betrek word. Die tweede gedeelte van hierdie artikel sal veral aandag wy aan wat tans bekend staan as emosionele intelligensie. Op albei gebiede bestaan daar leemtes in die huidige navorsing. Dit is byvoorbeeld opvallend dat Nuwe-Testamentiese navorsing oor die lewe van die nuwe mens veral geskied vanuit bepaalde gesigspunte. Ridderbos (1979:253) handel oor die oorsprong van die lewe van die nuwe 
mens en Lopez (1986:75-100) oor die verskillende aspekte van die nuwe mens in Efesiers 2 en 4. Veral die bevindinge van Lopez se behandeling van Efesiers 4 toon raakvlakke met wat in hierdie artikel beoog word. Lopez behandel die nuwe skepping, die innerlike mens, die nuwe mens en die aard van die nuwe mens, asook die aspekte van die "uittrek" van die ou mens en en die "aantrek" van die nuwe mens. Stott (1999:174) beklemtoon die kontras tussen die ou en die nuwe mens. Die ou mens én die nuwe mens lewe volgens verskillende standaarde. Die nuwe mens het ook 'n nuwe lewenstyl. Roberts (1991:140 e.v.) beklemtoon dat die lewe van die nuwe mens voortkom uit die diepste innerlike, uit die denke.

Navorsing oor die nuwe mens op die vlak van Pastoraal is beperk tot onderafdelings van omvattender werke. Adams (1980:233-248) behandel die nuwe mens onder die leerstuk van die heiligmaking. Campbell-Lane (2003:59-61) bespreek die vernuwing van die denke in die groter geheel van innerlike verandering.

Die navorsing op die vlak van emosionele intelligensie in die lewe van die nuwe mens sal ook op metateoretiese vlakke, byvoorbeeld die neurologie en psigologie, konsentreer. Dit is veral op hierdie vakgebiede dat navorsing gerig word op emosionele intelligensie. 'n Besondere stimulus vir navorsing oor emosionele intelligensie het voortgevloei uit die werke van Goleman (1997 en 1998), Bar-On en Parker (2000) en ook uit die navorsing van Salovey, Mayer en Caruso (2002). Op die Suid-Afrikaanse navorsingsterrein het Van Jaarsveld (2003) 'n besonder toeganklike en gefundeerde werk gepubliseer wat basiese kennis oor emosionele intelligensie begrond en konkretiseer. Ook die praktykgerigte werk van Vermeulen (1999) verdien vermelding.

Die basiese vrae wat in hierdie artikel ondersoek word, is die volgende: Watter lig bied toepaslike gedeeltes uit die Nuwe Testament op die oorsprong en lewenstyl van die nuwe mens? Hoe kan emosionele intelligensie nader omskryf word en wat is die wetenskaplike inhoud daarvan? Op watter vlakke van gedrag en lewenswandel kan emosionele intelligensie toepaslik gemaak word vir die pastorale wetenskap en in die praktiese bediening geïntegreer word?

Die navorsingsmetode wat gevolg is, is dié van analise, interpretasie en die sintese van toepaslike materiaal oor die navorsingsvrae.

Die verloop van die artikel is dat basisteoretiese gegewens oor die nuwe mens vanuit veral Efesiërs ontgin gaan word, gevolg deur 'n 
verkenning van metateoretiese data oor emosionele intelligensie. Afsluitend sal praktykteoretiese perspektiewe gebied word.

\section{Basisteoretiese perspektiewe op die nuwe mens en die lewe van die nuwe mens}

\subsection{Inleiding}

Die motivering waarom in hierdie artikel in besonder op twee briewe van Paulus gefokus word in die ontginning van basisteoretiese gegewens, is dat die uitdrukking ou en nuwe mens in die twee Briewe voorkom en nader uiteengesit en gekonkretiseer word in die lewenswandel en praktiese handelinge van die ou en nuwe mens.

In die Briewe van Paulus is daar veral drie gedeeltes waarin uitdruklik gehandel word oor die nuwe mens en die nuwe lewe. Die eerste deel is Efesiërs 2:13-15, veral vers 15. Die tweede is Efesiërs 4:20-24, veral vers 24 . Die derde is Kolossense 3:5-12, waar die opdrag in vers 10 gegee word om die lewe van die nuwe mens te leef.

In hierdie basisteoretiese onderafdeling sal veral nader ingegaan word op Efesiërs 4:20-24 en dan veral vers 24. Die motivering vir hierdie werkwyse is dat die uitdrukking "nuwe mens" in Efesiërs 2:15 primêr gerig is op die kerk as geheel; op die Christelike gemeenskap (vgl. Best, 1998:263), op die gelowiges as die liggaam van Christus (MacDonald, 2000:244). In die perikoop Efesiërs 4:20-24 word die lewe van die nuwe mens nie eerstens en direk verbind aan die kerk as gemeenskap nie. Die klem word eerder geplaas op individuele gelowiges en hulle lewe as nuwe mense. Hulle is as 't ware hier die samestellende dele van die een groot nuwe mensheid (vgl. O'Brien, 1999:331). Dit is juis die lewe van hierdie nuwe mense wat nader ondersoek gaan word. Verder is daar ook in Kolossense 3:5-12, bykans gelykluidend met Efesiërs 4:20-24, 'n nadere uiteensetting van die nuwe mens. Dit is so omdat Efesiërs en Kolossense 'n tweelingbrief is. In albei word oor die kerk gehandel. Tog is daar 'n nuanseverskil in die wyse waarop albei briewe die nuwe mens aan die orde stel. In Kolossense 3:5-12 word die vermaning om te lewe as nuwe mense bepaal vanuit die teenstelling tussen aardse en hemelse lewe, terwyl die vergelyking met die vorige heidense lewenswandel sekondêr gestel word. In Efesiërs word die lewe van die nuwe mens as teëstelling met die vorige, heidense lewenswandel, primêr en direk op die voorgrond gestel en behandel (vgl. Lincoln, 1990:289). 


\subsection{Die nuwe mens - 'n nadere omlyning}

Dit is vooraf nodig om Efesiërs 4:20-24 te plaas binne die geheel van die brief. Die tema van Efesiërs kan soos volg geformuleer word: Christus is die Hoof van die kerk, sy liggaam. Die brief kan breedweg in die volgende hoofdele ingedeel word ( $\mathrm{vgl}$. O'Brien, 1999:vii-vii): die inleiding (1:1-2), die nuwe mensheid - 'n skepping van God (1:3-3:21), die lewe van die nuwe mens (4:1-6:20), en die briefslot $(6: 21-24)$.

Efesiërs 4:17-24 hoort dus binne die onderafdeling wat handel oor die nuwe mens (4:1-6:20) en kan saamgevat word onder die tema: lewe soos die nuwe mensheid en nie soos die oue nie.

Om nou die ingrypende, algehele andersheid van die nuwe mens en sy lewe aan te dui, word dit gekontrasteer met die lewe soos dit vroeër was, die lewe wat hoort by heidene. Dit is 'n lewe waarin die heidene hulle oorgegee het aan losbandigheid om al wat vuil is te doen. Hierdie soort lewe is egter net die buitekant, die uiterlike aksie van dit wat innerlik verkeerd is. Die eintlike oorsaak, die diepste grond van hulle verkeerde dade, is gesetel in hulle denke.

Dit is opvallend hoe sentraal denke of gedagtes staan in verse 17 en 18. Die stam van die begrip nous word hier in elkeen van die uitdrukkings gebruik:

- Vers 17b: Die heidene se gedagtes lei tot niks nie. Hulle gedagtes is doelloos sonder 'n bepaalde eindpunt (vgl. Rienecker, 1980:186).

- Vers 18a: Hulle verstand is verduister.

- Vers 18c: Hulle volhard hardnekkig in hulle onkunde.

Tot drie maal word hier uitgespel dat die groot probleem in die lewenswandel van die ou mens wortel in dit wat hy/sy dink. Die herhaalde aanduiding van ' $n$ bepaalde denkpatroon beklemtoon dat 'n sondige lewe sy oorsprong vind in sondige denke. 'n Bepaalde gerigtheid en gesindheid in denke lei tot 'n bepaalde gerigtheid en gesindheid in lewenswandel en dade.

Juis op grond van die voorafgaande beredenering kan gestel word dat die grootste verskil tussen die ou en die nuwe mens nie eerstens in sondige dade of in 'n voorbeeldige en goeie lewenswandel gesetel is nie, maar in die denke. Dit is opvallend dat wanneer later van die aantrek van die nuwe mens gepraat word, dan word heel eerste, as 't ware met klem gestel waarin die nuwe van die nuwe 
lewe geleë is: word vernuwe in julle gees en gedagtes. 'n Mens word nuut as jy vernuut word in die gees van jou denke, in die diepste innerlike van jou denke. Floor (1995:168) wys daarop dat gees en gedagtes hier uitdrukkings is wat in betekenis naby aan mekaar lê. Die menslike gees is by Paulus die instrument om met God gemeenskap te beoefen. Die verstand of gemoed gee aan die mens die vermoë om te verstaan, te begryp. Hierdie verstaan of insig word vernuwe vanuit die gees van die mens wat op God gerig is. Vernuwing begin dus aan die "geestelike" kant van die mens. Vandaar uit verander ook die denke en insig. Dit is die gees (instelling, mentaliteit en gerigtheid) van die verstand wat sondig is en vernuut moet word.

Wat hierbo gestel is, is belangrik vir die tema van hierdie artikel (emosionele intelligensie in die lewe van die nuwe mens) omdat dade en wat gesê word, voortkom uit die gees wat die denke beheers.

\subsection{Die grond van die vernuwing in die denke van die nuwe mens}

Waarom moet die nuwe mens anders lewe as die heiden? Want hulle is anders geleer. Die uitdrukking leer of onderrig kom voor in vers 20: Julle het Christus nie so leer ken nie. Hierdie uitspraak hou in dat hulle Christus anders leer ken het. Hiermee wys Paulus weer terug na die lewenswandel van die heidene. Die seggingskrag van die uitdrukking: "nie so leer ken nie", hou positief in: Julle het Christus wel leer ken (vgl. Lincoln, 1990:279), maar op 'n heeltemal ander wyse. Hierdie ken is nie 'n blote intellektuele leeraksie nie, maar 'n lewe in 'n persoonlike verhouding met Christus (vgl. Muddiman, 2001:216; Floor, 1995:164).

Die "leer ken" in vers 20 word in vers 21 gevolg deur "is julle onderrig volgens die waarheid wat in Jesus is". Onderrig vind plaas deur hoor en hoor deur verkondiging. Hierdie verkondiging het as inhoud die werk van Christus.

Die werk van Christus is dus "aangeleer". Die herhaling van die aksie van leer in hierdie vers dui daarop. Dit is juis 'n kenmerk van die nuwe mens dat hy of sy "leerbaar" is. Langs die weg van leer van die werk van Christus, kan die nuwe mens die nuwe lewe toeeien en so nuwe mense bly en lewe as nuwe mense. 


\subsection{Uittrek en aantrek - tydstip en voortgaande proses in die lewe van die nuwe mens}

Die aksies om die ou sondige mens, die heidense leefwyse, af te lê (uit te trek) en nuut te word (die nuwe mens aan te trek) ontvang vervolgens aandag.

Dit is opvallend dat sowel in Efesiërs 4:20-22 as in Kolossense 3 dieselfde uitdrukking gebruik word vir aflê (uittrek), maar net in Kolossense word die term aantrek gebruik. Al drie werkwoorde staan in die medium en kan dus geïnterpreteer word as: julle moet vanself groot erns maak met die uittrek van die ou sondige mens en met die aantrek van die nuwe mens. Hierby kom ook dat vir aantrek en aflê aoristus-imperatiewe gebruik word. Dié gebruik dui op 'n opdrag om 'n bepaalde aksie vir eens en vir altyd af te handel, dit wil sê: lê nou finaal die ou mens af. Wanneer egter van die aantrek van die nuwe mens gepraat word in vers 23 , word die praesens gebruik om 'n voortdurende aksie aan te dui (vgl. O'Brien, 1999: 329). Dui die proses van aflê dan op iets wat eenmaal klaar en afgehandel is (vgl. Lopez, 1986:96 e.v.)? Hierdie saak moet eerstens heilshistorties beskou word. "Aflê" hou in dat die ou mens juis met die kruisiging en opstanding van Jesus Christus saam met Hom gekruisig is. Die ou mens is dood. So het ook die nuwe mens saam met Christus opgestaan (Rom. 6:6). Die nuwe mens lewe en op sy nuwe lewenswandel moet vordering en voortgang plaasvind. Floor (1995:167) stel dat die aksie van aflê van die ou mens egter ook heilsordelik beskou moet word. So het die aflê van die ou mens vanuit God se werk gesien - plaasgevind met die wedergeboorte wat bewerk is deur die Heilige Gees. Van die kant van die mens gesien, vind die aksie van aflê plaas wanneer die gelowige Christus aanneem (Kol. 3:9-10) by die bekering en die doop. Tog val aflê, bekering en doop ook nie saam nie; dit is 'n beginpunt waaruit die nuwe lewe geleef word. In aflê en aantrek gaan dit nie net en alleen om 'n herinnering aan die werk van Christus in die verlede nie. Dit gaan ook om 'n bevel in die hede (Floor, 1995:166). Die nuwe mens moet met sy lewe voortgaan vanuit God se groot vernuwingsdaad in Christus (vgl. O’Brien, 1999:331).

Die gedagte van vernuwing in die nuwe mens het ook 'n eskatologiese element. Die lewe van die nuwe mens moet gesien word binne die kader van reeds en nog nie. Die ou mens is reeds finaal afgelê. Dag na dag vorder die nuwe mens in innerlike vernuwing. Die voortgang op die pad van vernuwing is egter nog nie finaal en afgehandel nie: "... certain aspects of eschatological hope are reserved for future fulfilment" (Muddiman, 2001:220). 
In die opdrag om te leef as nuwe mens is egter nie net 'n nuanse van eskatologie nie, maar ook 'n nuanse van protologie. Die nuwe mens is geskape na die beeld van God (Gen. 1:26). In Efesiërs 4:24 word letterlik gestel dat die nuwe mens geskape is "according to God" (Muddiman, 2001:221). Hierdie uitdrukking bring die verhouding van die nuwe mens tot God in die visier. In dieselfde uitdrukking is verder die gedagte inbegrepe dat God nie net die Outeur van sy skeppingswerk is nie, maar ook die Model van die nuwe skepping - ook vir die lewe van die nuwe mens. Juis om hierdie rede word gestel dat die nuwe mens lewe in geregtigheid (as mense wie se saak met God in orde is). Hulle lewe ook in heiligheid as mense wat afgesonder is om hulle as nuwe mense te wy aan God. 'n Lewe "according to God" hou laastens ook in dat gelowiges wat reeds in beginsel deel is van God se nuwe skepping, hier sal lewe volgens hulle nuwe posisie (vgl. O’Brien, 1999:332).

\subsection{Konkretisering van aflê en aantrek in die lewe van die nuwe mens}

Vir die tema van hierdie artikel - emosionele intelligensie in die lewe van die nuwe mens - is dit van belang om ook basisteoreties vas te stel hoe die aflê van die ou mens en die aantrek van die nuwe mens konkretiseer volgens Efesiërs 4. In 4:25 tot 5:3 is duidelik twee fokuspunte te onderskei waarin die nuwe mens gestalte moet kry: die wyse van kommunikasie en die hantering van woede of aggressie. Toepaslike gedagtes word nou saamgevoeg en vergelyk om die twee fokuspunte na vore te laat kom.

\section{Die wyse van kommunikasie}

\begin{tabular}{|l|l|}
\hline By die ou mens & By die nuwe mens \\
\hline Vers 25: Valsheid & Vers 25: Die waarheid praat \\
\hline Vers 29: Vuil taal & $\begin{array}{l}\text { Vers 29: Praat wat goed en opbouend } \\
\text { is }\end{array}$ \\
Vers 30: Bedroef wel die Heilige Gees & $\begin{array}{l}\text { Vers 30: Bedroef nie die Heilige Gees } \\
\text { nie }\end{array}$ \\
\hline $\begin{array}{l}\text { Vers 31: Bitterheid, opvlieëndheid, } \\
\text { woede, vloek, skel, slegte dade }\end{array}$ & $\begin{array}{l}\text { Vers 32: Wees goedgesind, hartlik, } \\
\text { vergewe, volg die voorbeeld van } \\
\text { Christus, lewe in liefde }\end{array}$ \\
\hline
\end{tabular}

Twee sake kom in hierdie vergelyking na vore. Die eerste is die sentrale plek van die Heilige Gees in die kommunikasie tussen nuwe mense. Dit is juis wanneer nuwe mense kommunikeer asof die 
ou mens nog in hulle lewe, dat die Heilige Gees bedroef word. Hier staan letterlik in vers 30: Die Gees, die Heilige van God - hou op om Hom te bedroef. In ons kommunikasie met mekaar het ons met niemand minder te doen as met God wat heilig is nie. Die tweede saak wat uit die vergelyking na vore kom, is dat die uitdrukking aflê herhaal word in vers 25. Valsheid moet afgelê word. Aflê is 'n letterlike herhaling van die opdrag in vers $22 \mathrm{om}$ die ou mens af te lê. Die opdrag staan weereens in die medium om tot uitdrukking te bring: julle moet self erns maak om valsheid af te lê. Die eerste optrede van die nuwe mens kom juis in opregtheid teenoor sy naaste na vore; in besonder deur die waarheid te praat.

\section{Die hantering van woede}

\begin{tabular}{|l|l|}
\hline Die ou mens & Die nuwe mens \\
\hline Vers 26: Kwaad word en kwaad bly & $\begin{array}{l}\text { Vers 26: As hy wel kwaad word, pas } \\
\text { hy op om nie te sondig nie }\end{array}$ \\
\hline $\begin{array}{l}\text { Vers 31: Verbitterd, opvlieënd, } \\
\text { woedend bly, vloek, skel }\end{array}$ & $\begin{array}{l}\text { Vers 31: Nie 'n dag kwaad afsluit nie, } \\
\text { die duiwel nie 'n vatkans gee nie } \\
\text { Vers 32: Vergewe mekaar soos God } \\
\text { julle in Christus vergewe het } \\
5: 1: \text { Volg die voorbeeld van Christus } \\
5: 2: \text { Lewe in liefde }\end{array}$ \\
\hline
\end{tabular}

Wat uit hierdie vergelyking na vore kom, is dat dit wel in 'n gebroke bedeling gebeur dat mense vir mekaar kwaad word. Wat in hierdie gebrokenheid in die lewe van die nuwe mens na vore kom, is die wyse waarop hy woede hanteer - nie in bitterheid en skeltaal nie, maar wel in vergiffenis en liefde. In 'n gebroke bedeling kan niemand altyd kies wat, soms onverwags, met hom of haar gebeur nie. 'n Mens kan wel kies hoe jy reageer op dit wat met jou gebeur.

\subsection{Die lewe van die nuwe mens en die betoning van empatie}

Die term empatie hou in om deur die oë van iemand anders te kyk en om te kan voel soos iemand anders voel sonder om self so subjektief betrokke te raak dat hulp nie gebied kan word nie. Hierdie term self kom nie in die Nuwe Testament voor nie, maar die saak wel. Die stelling word nou nader uitgewerk omdat die vermoë om 
empatie te kan betoon, ' $n$ wesensdeel van emosionele intelligensie is.

'n Vergelyking tussen Efesiërs 4:17-5:5 en Romeine 12:1-21 toon verskillende ooreenkomste aan wat verband hou met die fokuspunt van hierdie artikel. In Romeine 12:2 word gestel: laat God julle verander deur julle denke te vernuwe. In Efesiërs 4:23-24 staan: julle gees en julle gedagtes moet nuut word, lewe as nuwe mense. 'n Verdere punt van ooreenkoms is dat in Efesiërs 4, ná die uiteensetting van die lewe van die nuwe mens, riglyne volg vir die nuwe lewe. Romeine 12 bied 'n uiteensetting van God se ontferminge en dan volg riglyne vir die nuwe lewe op grond van God se ontferminge. Die wyse waarop die nuwe mens met sy geloofsgenote en ander mense saamleef, word as 't ware by wyse van drie wyer wordende sirkels van liefdesbetoon in Romeine 12:9-21 uiteengesit.

\begin{tabular}{|l|l|l|}
\hline $\begin{array}{l}\text { Kleinste sirkel } \\
\text { Liefdesbetoon teenoor } \\
\text { medegelowiges }\end{array}$ & $\begin{array}{l}\text { Tweede, groter sirkel } \\
\text { Liefdesbetoon teenoor } \\
\text { alle mense }\end{array}$ & $\begin{array}{l}\text { Die wydste sirkel } \\
\text { Liefdesbetoon teenoor } \\
\text { vyande }\end{array}$ \\
\hline $\begin{array}{l}\text { Vers 9: Die liefde moet } \\
\text { opreg wees }\end{array}$ & $\begin{array}{l}\text { Vers 17: Wees goed- } \\
\text { gesind teenoor alle } \\
\text { mense }\end{array}$ & \\
\hline $\begin{array}{l}\text { Vers 10: Betoon hartlike } \\
\text { broederliefde }\end{array}$ & $\begin{array}{l}\text { Vers 18: Leef in vrede } \\
\text { met alle mense }\end{array}$ & $\begin{array}{l}\text { Vers 13: As jou vyand } \\
\text { honger of dors is, gee } \\
\text { hom kos en water }\end{array}$ \\
\hline $\begin{array}{l}\text { Vers 13: Help die mede- } \\
\text { gelowiges in hulle nood }\end{array}$ & & \\
\hline
\end{tabular}

Dit gaan in hierdie uitkringende liefdesbetoon om omvattende liefdesbetoon en opregtheid. Tog is binne hierdie opdragte tot liefdesbetoon 'n besondere aanduiding van empatie.

- Vers 13 veronderstel 'n benadering in empatie:

Help die medegelowiges in hulle nood ... lê julle toe op gasvryheid.

- Vers 15 is ook 'n sprekende voorbeeld van 'n benadering in empatie:

Wees bly saam met die wat bly is en treur saam met die wat treur. 
2.7 Die lewe van die nuwe mens as die herkenning en uitspreek van gevoelens

'n Basiese vereiste vir emosionele intelligensie is dat 'n mens jou eie gevoelens moet kan herken en toepaslik kan uitspreek. Hieroor word nou kortliks gehandel op basisteoretiese vlak.

In 'n indringende artikel gaan Kruger (2003:89 e.v.) in op emosies en die uitspreek daarvan in die Ou-Testament. Hy beskou emosies as 'n menslike respons op uitdagings in die omgewing waarin 'n nuutgemaakte mens 'n stryd voer om te oorleef. Verder het emosies ook ten doel om jou diepste gevoelens aan ander bekend te maak (Kruger, 2003:91; vgl. Lotter, 2004:1; Van Jaarsveld, 2003:65 e.v.).

In die Ou Testament is die herkenning en uiting van gevoelens prominent, veral in Psalms. In Psalm 32 stel Dawid: ek het my sonde bely; vers 5: voor die Here bely ek my opstandigheid. Gevoelens van skaamte en opstandigheid kom voor in Esegiël 7:18 waar gesê word: elke gesig sal verslae wees.

In die Nuwe Testament spreek Paulus meermale sy gevoelens uit. In Romeine 9:3 sê hy: daar is by my groot droefheid en voortdurende hartseer oor my broers, my eie volksgenote. In Filippense 3:18 spreek Paulus sy gevoelens so uit: Ek het dikwels vir julle gesê en tot my verdriet moet ek dit nou herhaal ...

Teenoor die Tessalonisense verklaar Paulus sy gevoel soos volg: ons was liefdevol en sag teenoor julle soos 'n ma wat haar kinders vertroetel.

\subsection{Samevattende stellings}

- Die kern van die nuwe lewe is om reg te dink. Die gerigtheid en gesindheid van denke bepaal die lewe en gedrag van die nuwe mens.

- Langs die weg van leer word die nuwe lewe toegeëien.

- Die lewe en optrede van die nuwe mens moet langs die weg van leer 'n lewe "according to God" (kata theon) wees.

- Die uittrek van die ou mens het reeds finaal plaasgevind. Die aantrek van die nuwe mens moet voortdurend plaasvind.

- Die lewe van die nuwe mens konkretiseer in sy manier en gesindheid van kommunikasie en in die hantering van eie woede.

- Die nuwe mens word gekenmerk deur sy optrede in empatie en ook in die herkenning en gepaste uitspreek van sy eie gevoelens. 


\section{Metateoretiese perspektiewe}

\subsection{Definiëring van emosionele intelligensie}

Salovey, Mayer en Caruso (2002:160) neem as vertrekpunt vir hulle besinning op wat ons vandag emosionele intelligensie noem, 'n stelling wat Mowrer in 1960 gemaak het dat " ... the emotions ... do not at all deserve being put into opposition with intelligence ... they are, it seems, themselves a higher order of intelligence". Sedert hierdie omskrywing in 1960 was daar telkens verwysings na emosionele intelligensie. In 1990 omskryf Salovey, Mayer en Caruso (2002:160) emosionele intelligensie op grond van hulle navorsing as "... the ability to understand feelings in the self and others, and to use these feelings as information guides for thinking and action". Bogenoemde drie outeurs beredeneer ook in 'n ander artikel (Salovey, Mayer \& Caruso, 2000:92-113) dat emosionele intelligensie per definisie ook beskou kan word vanuit drie dimensies, naamlik in direkte verband met 'n heersende tydsgees, vanuit menslike persoonlikheid en ook as 'n bepaalde verstandsvermoë. In dieselfde jaar omskryf Bechara, Tranel en Damasio (2000:211) emosionele intelligensie as "... a collection of emotional abilities that constitute a form of intelligence that is different from cognitive intelligence or IQ".

Die definisie van Goleman (1998:317, vgl. ook Goleman, Boyatzis \& McKee, 2002:102-104) kan beskou word as 'n verlengstuk van die vorige definisies. Hy omskryf emosionele intelligensie as "the capacity for recognizing our own feelings and those of others, for motivating ourselves, and for managing emotions well in ourselves and in our relationships". Emosionele intelligensie moet dus onderskei word van akademiese intelligensie wat bepaal word deur die meting van die IK. Tog is emosionele en akademiese intelligensie aanvullend tot mekaar; hulle gee uitdrukking aan die aktiwiteite van verskillende dele van die brein (vgl. Goleman, 1997:4 e.v.)

'n Meer resente definisie van emosionele intelligensie kom van Boyatzis, Goleman en Rhee (2000:344) en lui so:

... emotional intelligence is observed when a person demonstrates the competencies that constitute self-awareness, selfmanagement, social awareness, and social skills at appropriate times and ways in sufficient frequency to be effective in the situation.

Wat opval in die voorafgaande definisies, is dat hoewel menslike persoonlikheid ' $n$ rol speel in emosionele intelligensie, meer presies in die wyse waarop emosionele intelligensie aangewend word, die 
klem in emosionele intelligensie geplaas word op gevoelens, selfbewussyn, "ability," "capacity" en "competence" om eie en ander se emosies raak te sien, te interpreteer en te hanteer (vgl. Burnard, 1992:5-16; Bar-On, 2001:87-88.)

Vanuit die basisteoretiese bevinding dat die lewe van die nuwe mens direk verbind word aan die feit dat die mens na God se beeld geskape is, word hier gestel dat die mens se "abilities, competencies en capacities" wat uit die verskillende definisies na vore gekom het, en in emosionele intelligensie funksioneer, hier vanuit 'n bepaalde perspektief beoordeel moet word, naamlik vanuit die basisteoretiese vasstelling dat die mens geskape is "according to God", met ander woorde volgens die beeld van God (vgl. ook Louw, 1999:31-33.) Hierdie vermoëns en moontlikhede van die mens dra nie by tot saligheid nie, maar is gawes van God aan hulle wat na sy beeld geskep is. Alle mense is na die beeld van God geskep, maar hierdie gawes, ook gawes van emosionele intelligensie, kom tot besondere ontplooiing in die lewe en gedrag van die nuwe mens, omdat die werk van die Heilige Gees sentraal staan in die lewe van die nuwe mens.

\subsection{Modelle vir die meting van emosionele intelligensie}

Die huidige stand van navorsing in die Psigologie toon dat daar tans veral twee modelle is wat gebruik word vir die meting van emosionele intellligensie (Salovey, Mayer \& Caruso, 2002:163-164). Die eerste is die MEIS (Multifactor Emotional Intelligence Scale). Hierdie skaal word gebruik om 'n twaalftal vermoëns in vier vertakkinge te meet. Hierdie vertakkinge is die volgende:

- die waarneem en uitspreek van gevoelens;

- die gebruik van emosies om denk- en ander kognitiewe handelinge te fasiliteer;

- die verstaan van emosies en

- die hantering van emosies in 'n persoon self en in ander persone.

Die tweede skaal wat as 'n nadere verbesondering en verfyning van die eerste beskou kan word, is die MSCEIT (Mayer, Salovey \& Caruso Emotional Intelligence) skaal. 


\subsection{Groepering van vermoëns in emosionele intelligensie}

Goleman (1998:318) groepeer vermoëns in emosionele intelligensie in vyf onderafdelings en onderskei ook intra- en interpersoonlike dimensies hierin:

\section{Selfbewussyn}

Die uitdrukking, wat hier net kursories genoem word, is 'n vertaling van die Engelse woord self-awareness en veronderstel ook 'n nuanse van selfinsig. Selfbewussyn hou in om te weet wat jy op 'n sekere oomblik voel, om hierdie wete te kan verwoord en om dit te implementeer in besluite wat op daardie oomblik geneem word. Selfbewussyn hou ook in om 'n nugter beskouing te hê van eie vermoëns en 'n goedgefundeerde gevoel van selfvertroue (vgl. Ferrari \& Sternberg, 1998).

\section{Selfbeheer}

Selfbeheer omvat die vermoë om eie emosies te hanteer om dienstig te wees aan die taak wat verrig moet word; om betroubaar en nougeset te wees, erkenning en vergoeding uit te stel, om 'n bepaalde doelwit na te streef, om goed te herstel van emosionele letsels en om innoverend en aanpasbaar te wees. Hiermee saam gaan 'n groeiende beheer van frustrasie, aggressie en dus ook van woede-uitbarstings.

\section{Selfmotivering}

So 'n persoon sal sy of haar diepste voorkeure en prioriteite benut om sy doelwitte te bereik, inisiatief te neem en te streef na uitnemendheid. Sterk motivering ondersteun hom of haar ook om te volhard te midde van teenslae en frustrasie. Hy of sy bly inisiatief behou en is optimisties.

\section{Empatie}

Empatie hou in om te voel wat ander voel, om te kyk vanuit hulle perspektief en ooreenstemming te soek en te onderhou met soveel persone as moontlik. Hiervoor word vereis 'n bewustheid van die "kultuur" in 'n bepaalde organisasie, diensgerigtheid, toerusting van kollegas en die benutting van diversiteit in 'n organisasie.

\section{Sosiale vaardighede}

Om sosiale vaardighede te hê beteken om emosies in onderlinge verhoudinge goed te kan hanteer, emosionele situasies reg te kan opsom, om goed met mense om te gaan en om eie vaardighede te 
gebruik om te oortuig, leiding te neem, te onderhandel, verskille op te los en te kan saamwerk in spanverband. Leierskap, kommunikasie, konflikhantering, die smee van bande - dit alles vorm deel van sosiale vaardighede (vgl. ook Boyatzis, Goleman \& Rhee, 2000:355; Collins \& Collins, 2001).

\section{4 'n Nadere uiteensetting van bepaalde toepaslike aspekte van emosionele intelligensie in die lewe van die nuwe mens}

\subsubsection{Selfbewussyn}

Dit is reeds hierbo gestel dat ' $n$ kardinale dimensie in emosionele intelligensie 'n nugter selfbewussyn is. Omdat selfbewussyn ook kennis van die self veronderstel, moet hier kortliks oor die plek van die self in die selfbewussyn gehandel word.

Burnard (1992:6-23) onderskei verskillende aspekte van die self. Daar is 'n dimensie van liggaamlikheid in die self. So kommunikeer ons byvoorbeeld soms in liggaamstaal deur oogkontak, gebare en aanraking. Daar is voorts die dimensie van die werklike self. Dit is die dimensie wat alleen 'n mens self goed ken, en dalk 'n paar ander persone, maar wat hoofsaaklik vir ander verberg word.

Sowel Van Jaarsveld (2003:28) as Burnard (1992:9) beredeneer dat dit wat ons vir ander wegsteek, presies ooreenkom met wat ander van hulleself vir ons wegsteek "... what is most personal is most general". Hierdie stelling herinner daaraan dat reeds Carel Rogers (1951:126) hierdie waarheid onderstreep het en dat Nouwen (1981:98), 'n bekende spiritualiteitskrywer, al hierop voortgebou het (vgl. ook Dreyer, 2003:718). Vervolgens is daar ook die ideale self wat tot uitdrukking bring hoe ons graag sou wou wees. Ideale self en werklike self is op meer vlakke dikwels teenstellings (vgl. ook Carver \& Scheier, 1998:113). Daar is ook 'n aspek wat genoem kan word die self vir buitestanders. Persone van buite het dikwels 'n ander beskouing van ons as onsself. Hieroor het Povinelli en Prince (1998:37-95) uitvoerig gehandel. Van belang is dat ander persone teenoor ons optree asof hulle beskouing van ons die korrekte is. Vervolgens kan ook die sosiale self onderskei word. Hiermee word bedoel die wyse waarop 'n persoon ingelei word en optree binne die bepaalde waardes in 'n sekere gemeenskap of situasie. Die term spirituele self het veral te doen met die soek, vind en realisering van ' $n$ bepaalde singewing in die lewe. Dit is opvallend dat Burnard (1992:19) ' $n$ volgende aspek in die self belig as die donker self. Dit is bepaalde aspekte in ons waarvan ons self nie hou nie, en ook nie 
maklik oor sal praat nie, byvoorbeeld gedagtes gelaai met aggressie teenoor ander, bepaalde gedagtes oor seksualiteit, ensovoorts. Laastens word seksualiteit onderskei as 'n dimensie van die self, waarin dit veral gaan oor seksuele identiteit en oriëntasie.

Vermeulen (1999:8-9) onderskei vier areas waarin ons vanuit die self energie belê, naamlik die spirituele (vervulling), fisiese (gesondheid), emosionele (verhoudings) en verstandelike (sukses).

In die lig van die uiteensetting van die self in elke mens kan nou verder aandag gegee word aan die aspek van selfbewussyn in emosionele intelligensie. Carver en Scheier (1998:31) omskryf selfbewussyn as "... focusing the attention on an aspect of the self. (...) [that is] selective processing of information about the self" (vgl. Ciarocchi, Forgas \& Mayer, 2001:74). Goleman (1997:303) konkretiseer sy definisie van selfbewussyn as "... observing yourself and recognizing your feelings, building a vocabulary for feelings, knowing the relationship between thoughts, feelings, and reactions". In wese het selfbewussyn dus te doen met 'n voortgaande proses om te wete te kom wie jy is. Burnard (1992:25) praat in hierdie voortgaande proses van "inner and outer experience". Onder eersgenoemde ("inner experience") word verstaan hoe ons innerlik oor onsself voel en onder laasgenoemde ("outer experience") wat ander mense van ons sien en ervaar (vgl. ook Woodman, 1973).

Die dimensie van selfbewussyn omvat veral drie hoofsake (Goleman, 1998:54-55):

- Die eerste is om bewus te wees van eie emosies wat ervaar word en waarom dit ervaar word en om hierin ook die verband te erken tussen eie gevoelens en wat gedink, gedoen en gesê word in 'n bepaalde situasie.

- Die tweede deel van die proses in die selfbewussyn is om jouself nugter te kan evalueer. Hierdie evaluering omvat sterk punte en beperkinge. Saam hiermee gaan insig waar verbeteringe moet plaasvind en ook die vermoë om uit ervaring te leer.

- Die derde aspek van die selfbewussyn is gesonde selfvertroue, die moed om seker te wees van eie vermoëns, waardes en doelwitte.

Omdat 'n gesonde selfbewussyn die fondament is van emosionele intelligensie, dra dit by tot selfverstaan, tot aanvaarding van ander en tot die vermoë om moeilike situasies te hanteer. Hierby kan ook gevoeg word dat die selfbewussyn die bewuste gebruik van die self 
en sodoende van persooonlike outonomie bevorder (vgl. Burnard, 1992:29).

\subsubsection{Emosies}

Vir die doeleindes van hierdie artikel word emosie as sinoniem beskou vir gevoel en omskryf as "an internal state that often results from our thoughts, it can be pleasant or unpleasant and can motivate our behavior" (Bedell \& Lennox, 1997:68). Daar is 'n nou verbinding tussen gedagte en gevoel. 'n Gedagte is 'n boodskap van die brein wat 'n wens, begeerte of verwagting verwoord. Hierdie gedagtes dien as 'n sneller vir die aktivering van gevoelens. Gevoelens vind dus hulle oorsprong in denke. Die belangrike gevolgtrekking op grond hiervan is dat gevoelens as gevoelens nie verander nie, maar dit wat 'n mens dink, die oorsprong van gevoelens, kan verander. So kan ons reaksie op gevoelens verander en beheer word (vgl. Vermeulen, 1999:43).

Gevoelens moet weer onderskei word van stemminge wat langer duur as 'n emosie en dikwels met swye gepaard gaan. Hierby moet ook rekening gehou word met die konsep van temperament, wat 'n stemming van neerslagtigheid, vrees of vreugde kan teweegbring (vgl. Goleman, 1997:290; Snyder \& Lopez, 2002).

Daar is waarskynlik tientalle gevoelens of emosies wat in 'n mens se lewe kan voorkom en tot uiting kan kom. Die vraag hier is of 'n breë indeling van gevoelens moontlik is. Goleman (1997:290) beskou die werk wat Ekman op hierdie gebied gedoen het as rigtinggewend. Ook Bedell en Lennox (1997:68) het hieroor bydraes van waarde gelewer. Volgens hierdie navorsers is dit moontlik om emosies in vier hoofgroeperinge te verdeel tesame met gedagtes wat met hierdie emosies gepaard gaan of dit opwek. Die vier basiese emosies is:

- Vrees: Vrees is 'n prominente emosie wanneer iemand verwag dat iets gaan gebeur wat hy of sy nie wil hê moet gebeur nie.

- Woede: Woede tree in wanneer iemand 'n gevoel ervaar dat hy of sy iets wil hê, dit nie kry nie, en dit steeds wil hê.

- Droefheid: Droefheid word ervaar as 'n persoon iets graag wil hê, dit nie kry nie en hoop opgee om dit ooit te kry.

- Gelukkigheid: Hierdie emosie word ervaar wanneer iemand iets graag wil hê en dit wel kry. 
Vir ons onderwerp is dit van belang om die moontlike indeling van verskillende emosies onder elkeen van hierdie hoofgroeperinge na te gaan (vgl. Bedell \& Lennox, 1997:54).

Met vrees kan gepaard gaan gevoelens van spanning, angstigheid, bangheid, kommer, verskrikking, senuweeagtigheid, bewerasie, ontsetting, ongemak.

Met woede word geassosieer emosies van irritasie, ergerlikheid, gegriefdheid, uitbranding, gespannenheid, bitterheid, gekrenktheid, kwaad wees.

Die emosie van droefheid kan gevoelens na vore laat kom soos hooploosheid, uitsigloosheid, ontmoediging, in die put wees, vermoeidheid, ongelukkigheid, vreugdeloosheid.

Gevoelens van geluk kan na vore kom in bevrediging, tevredenheid, blydskap, opgewektheid, lighartigheid, voldaanheid, behaaglikheid.

Die volgende gevoelens word as moeilik beskou om onder een groepering tuis te bring: ontsteltenis, skugterheid, onbekwaamheid, onveiligheid, stilte, onvoldaanheid, slegtigheid, 'n gevoel dat iets skrikwekkend is, gevoelens van kranksinnigheid.

\subsubsection{Die funksie van die amigdala in die emosionele lewe en emosionele reaksie ${ }^{1}$}

Miskien is dit so dat die funksionering van emosies in sake soos besluitneming en ingrypende optredes reeds lank 'n verwaarloosde aspek was in neurologiese navorsing. In die jongste tyd het hierdie aspek egter weer belangstelling in verdere navorsing gestimuleer. Volgens Goleman (1997:18) is indringende navorsing deur Ekman en LeDoux gedoen oor die funksie van die brein en menslike emosies. Dit is navorsing wat nuwe lig kan werp op die onderwerp van hierdie artikel. In die sentrum van die navorsing staan veral die funksie van die sogenaamde amigdala, die amandelvormige dele in die anterior dele van die temporale lobbe van die brein, sowel links as regs. Dit vorm deel van die sogenaamde limbiese/primitiewe brein en word ten nouste geassosieer met emosies. Die amigdala het 'n uitgebreide neurologiese netwerk na ander dele van die brein (vgl. Bechara, Tranel \& Damasio, 2000:196, 202; Taylor \& Bagby, 2000:51, 52; Vermeulen, 1999:50-52). Die amigdala ontvang inlig-

1 Dank en erkenning word hiermee verleen aan dr. Renata Schoeman, senior kliniese assistent (registrar), Departement Psigiatrie, Universiteit Stellenbosch, vir haar kontrole en inset ten opsigte van hierdie onderafdeling (3.4.3) - CJHV. 
ting uit die omgewing (visie, gehoor, pyn, tas en reuk) via die thalamus wat as "relay station" dien. Byvoorbeeld: by die visuele waarneming van gevaar (soos 'n leeu wat jy skielik sien) word twee roetes gevolg. Met die eerste roete (die shortcut) gaan die inligting direk na die amigdala wat dan die "veg- en vlug"-reaksie inisieer via uitsette na die hart (toename in tempo), spiere (toename in bloedvloei), of selfs "verlamming" van dele van die spinaalkoord ("being paralysed with fear"). Die meeste van dié reaksies vind plaas onder die invloed van die streshormone kortisol en adrenalien. Onder hierdie omstandighede registreer die persoon dan net die volgende: "Gevaar!" "Wees bang!" "Vlug!" Eers nadat die roete geaktiveer is, word die tweede roete (die sogenaamde high road) geaktiveer. Hier gaan die inligting uit die omgewing eers na die thalamus wat dan die inligting herlei na die korteks en dan "besluit" of die amigdala geaktiveer moet word vir die gepaardgaande emosie/vrees. Die persoon is dan in staat om die gevaar in konteks te sien (bv. die leeu is in 'n hok/blind/versadig) en die amigdala word toepaslik geaktiveer ("verligting").

Dit kom dus daarop neer dat die amigdala 'n emosionele respons kan aktiveer nog voordat die visuele korteks self ten volle ontleed het wat besig is om te gebeur en 'n meer deurdagte emosie en antwoord met 'n ompad na die amigdala kan stuur vir 'n meer verantwoorde reaksie (vgl. Goleman, 1997:19).

Die inwerkingstelling van die veg- of vlug-aksie is egter nie die enigste taak van die amigdala nie. Die amigdala is ook 'n soort "emosionele hek" na die herinneringsbank van die hippocampus, een van die sleutelstrukture ten opsigte van geheue. Die brein "bêre" herinneringe op twee wyses, naamlik deur middel van feitelike geheue en deur middel van emosionele geheue. As jy met ander woorde 'n leeu sien, herken jy hom as 'n leeu (feitelike geheue), maar die amigdala versnel dan die emosionele aspekte van die geheue, byvoorbeeld die vrees vir die leeu (nadat 'n mens byvoorbeeld 'n televisieprogram oor ' $n$ mensvreterleeu gesien het). Goleman (1998:20) praat in hierdie verband van die amigdala as "the specialist in emotional memory". Wat hierbo uiteengesit is, hou dus in dat die baie vinnige reaksie van die amigdala (binne breukdele van 'n sekonde) voortgaande reaksie verder stimuleer deur ook nog assosiasies (byvoorbeeld van haat, woede, verontregting) daarby te voeg. Hierdie assosiasies van wat in die verlede gebeur het, is vasgelê in die emosionele geheue. Dit is dus duidelik dat die amigdala 'n belangrike rol het in assosiatiewe geheue/ leeraspekte. 
Vir insig in en beheer van eie emosies en vir begrip en die hantering van ander se emosies - as 'n belangrike aspek van emosionele intelligensie - is hierdie vaslegging belangrik. Dit is dalk vandag nie so dikwels 'n vlugreaksie wat op die voorgrond is nie, maar eerder wat Goleman (1997:13) 'n "emotional hijacking" noem, en wat Burnard (1992:70-71) aandui as "the last straw syndrome." Tydens so 'n situasie van emosionele uitbarsting word die sneller deur die amigdala getrek om te reageer terwyl die prefrontale deel van die brein, wat die emosies beheer, as 't ware oorspoel word deur die emosionele deel van die brein. Hierby kom ook nog dat die emosionele brein werk met assosiasie. Dit beskou elemente wat 'n sekere werklikheid voorstel as die werklikheid self en reageer daarop, want "things are as they seem" (Goleman, 1997:294.

\subsubsection{Samevatting}

Die kern van emosionele intelligensie trek saam in die vermoë om eie gevoelens in jouself te herken en uit te spreek en ook om gevoelens in ander te herken en te hanteer. Hierdie uitgespreekte gevoelens dien dan as inligting oor eie denke of die denke van 'n ander en as riglyne van aksie.

Vermoëns in emosionele intelligensie wat 'n kardinale plek inneem, sluit die volgende in: selfbewussyn, selfbeheer, selfmotivering, empatie en sosiale vaardighede.

Emosies ontspring in die denke, kan aangenaam of onaangenaam wees en motiveer bepaalde gedrag. Die vier mees basiese emosies is vrees, woede, droefheid en gelukkigheid.

Vir emosionele intelligensie is kennis van en insig in die funksionering van die amigdala noodsaaklik, naamlik dat die amigdala die sneller trek vir veg of vlug en ook dien as 'n geheuebank vir gebeure in die verlede wat die veg- of vlugaksie in 'n bepaalde (assosiatiewe) konteks plaas.

\section{Praktykteoretiese perspektiewe}

Vanuit die gesigspunte soos blootgelê in hierdie artikel word nou in besonder gefokus op die pastorale integrering van sommige aspekte van emosionele intelligensie in die praktiese lewe van en bediening aan die nuwe mens. 


\subsection{Die pastorale benaderingsvlak}

In die ontginning van die basisteoretiese gegewens is vasgestel dat elke mens geskape is "according to God," dit wil sê volgens die beeld van God. In die voorafgaande ontginning van toepaslike gegewens is die gesindheid en gedrag van die ou en die nuwe mens ook aangedui. Hierdie vertrekpunt bied riglyne vir die benaderingsvlak in die herderlike bediening.

Pastorale sorg word verrig vanuit die pastor en die gemeentelede se geskapenheid "according to God" (Grieks: kata theon). Hierdie benadering bied nie net op praktiese vlak 'n platform vir bediening aan hulle wat nog leef op die wyse van die ou mens nie. Dit bied ook kongruensie met hulle wat reeds lewe as nuwe mense in radikale teenstelling met die gedragswyse van die ou mens.

Hierbenewens bied die bepaalde benaderingsvlak aan die pastor self die grondslag vir 'n spesifieke selfbewussyn en selfinsig in die hantering en uitspreek van sy eie gevoelens. Hy is self ook geskep na die beeld van God. Op hierdie wyse kom die optrede van die nuwe mens prakties na vore in die versorging van nuwe mense.

'n Volgende aspek van die geskapenheid van sowel pastor as gemeentelede "according to God" is dat God self as 't ware die Model is - nie net vir die geskapenheid van die nuwe mens nie maar ook vir die gedrag van die nuwe mens. Juis die feit dat vasgestel is dat die nuwe mens behoort te lewe in ooreenstemming met sy nuwe gedragswyse, bied die Skriftuurlike grond vir gerigte vermaning - en nie vir moraliserende vermaning nie - om wel te lewe as nuutgemaakte mens. Dit is hierdie nuutheid wat konkreet word in die wyse waarop bedienaar en gemeentelede, en gemeentelede onderling, met mekaar saamlewe, kommunikeer en hulle eie toorn, woede en aggressie teenoor mekaar hanteer en ook in die begrip wat hulle vir mekaar se gebreke het.

\subsection{Die praktiese hantering van woede in die lewe van die nuwe mens}

Aan die nuwe mens - so is vasgestel in die eksegetiese gedeelte word die eis gestel om die ou mens af te lê en om te leef in selfbeheersing. Vanuit die Psigologie is die werking van die amigdala nader uitgewerk en aangetoon dat 'n woedereaksie meestal oorhaastig en ondeurdag geskied.

Die praktiese hantering van die woede in die nuwe mens hou in dat iemand nie oombliklik verdedigend en oorrompelend moet reageer 
wanneer hy kwaad word nie. Selfinsig en selfbeheersing bly pastoraal 'n vereiste om eie emosies en impulse te beheer. ' $n$ Hanteringswyse sou dan kon wees om eers vir ses tellings te swyg en diep asem te haal en sodoende 'n ontspanningseffek teweeg te bring. In 'n ekstreme geval van woede is dit beter om te vra om vir 'n langer periode verskoon te word uit die woedesituasie om eers tot volle selfbeheer te kom. 'n Praktiese hanteringswyse kan wees om nadat gekalmeer is - selfs 'n dag later - met die betrokke pastor of lidmaat 'n gesprek te voer. Dan kan die rede vir die gevoelens van aggressie in 'n kalm stemtoon verwoord, die oorsaak daarvan geïdentifiseer en 'n moontlike oplossing aangebied word.

\subsection{Begeleiding in die wyse van denke}

In die ontginning van Skrifgegewens het na vore gekom dat die lewe van die ou mens beheers word vanuit 'n ou (heidense) wyse van denke. Die nuwe mens dink nuut. Navorsing oor die psigologiese aspekte van emosionele intelligensie het getoon dat emosies voortvloei uit wat gedink word. Uit pastorale hoek is dit dus belangrik om in aanmerking te neem en in gedagte te hou dat denke die sneller is en bepalend is vir emosies. Mense vrees byvoorbeeld nie eerstens ' $n$ bepaalde persoon of situasie nie. Wat hulle dink oor 'n bepaalde persoon en situasie, met ander woorde hulle persepsie daaroor, laat vrees ontstaan. Die emosie van vrees as sodanig verander nie. Die wyse waarop gedink word oor die rede vir die emosie vir vrees, verander die emosie. Juis daarom is dit noodsaaklik om deur te dring na die denke onderliggend aan die emosie en dan die herderlike begeleiding daarop toe te spits. So word, vanuit die hoek van emosionele intelligensie beskou, ou denke deur nuwe denke vervang. In die lig van Romeine 12:2 dat denke vernuwe moet word, behoort aandag gewy te word aan hierdie dinamika van die verandering van emosies deur verandering in denke - ook deur in die prediking en ander bedieningsgestaltes hierop te fokus. Uiteraard bly die werk van die Heilige Gees hierin sentraal staan. Nuwe denke oor redes vir vrees geld vir sowel pastor as gemeentelede. 'n Pastor mag ook 'n bepaalde vrees koester oor die moontlike reaksie van lidmate of oor sekere sake. Die kern is dat hy moet kom by die wyse waarop hy dink oor lidmate se moontlike reaksie as rede vir sy vrees.

\subsection{Die aanleer van die gedrag van die nuwe mens.}

Aangeleerde sondige gedrag kan wel afgeleer word. Die bevinding in die basisteoretiese uiteensetting dat die gedragswyse van die nuwe mens aangeleer word deur Christus te leer ken langs die weg 
van Skriflesing, verkondiging en gebed, bring die aspek van gesonde gewoontevorming in perspektief. Gesonde gewoontes in die beoefening van die omgang met en vorming van 'n persoonlike geloofsverhouding met Christus is noodsaaklik vir die ontstaan, groei en voortgang - en ook vir die gedrag - van die nuwe mens.

\subsection{Bediening in empatie}

Uit Paulus se opdragte vir die optrede van nuwe mense teenoor mekaar het die dimensie van empatie sterk na vore gekom. Psigologies hou empatie in om deur die oë van 'n ander te kyk en om te voel vanuit sy of haar gevoelens. Empatie is, vanuit die hoek van emosionele intelligensie beskou, 'n kardinale vereiste in die bediening en onderlinge meeleef van God se nuwe mense. Empatie kan beskou word as ' $n$ eerste konkretisering van God se liefde vir ons, ons liefde vir God, vir mekaar onderling, vir alle mense en vir vyande. Pastoraal gesproke, vereis bediening in empatie 'n helder selfbewussyn van pastorale identiteit, van eie gevoelens en ook van ander se gevoelens en die hantering daarvan binne die gebroke werklikheid. Op praktiese vlak kom empatie in die bediening na vore in 'n kreatiewe luisteraksie, dit wil sê om vanuit 'n innerlike meegaan met 'n ander, aanvaardend, nadenkend, observerend en vragend te luister. Om aanvaardend te luister beteken nie om 'n sondige lewenswyse van die ou mens in die lewe van die nuwe mens goed te keur nie. Dit beteken wel om die ander met sy eie gevoelens en nood te aanvaar as geskape "according to God".

\subsection{Bediening aan die nuwe mens in eskatologiese perspektief}

Herder en lidmate as nuwe mense leef tans nog in hierdie gebroke bedeling van reeds en nog nie. Aan hierdie bedeling is dit eie dat voortgang en terugval steeds sal bly plaasvind. In die gedrag en optrede van die nuwe mens moet hierdie aspekte verdiskonteer word. Daar is nog nuwe mense wat weer terugval in alkoholmisbruik, in egskeidings betrokke raak en diefstal pleeg. Daar is nog gelowige kinders wat aan dwelms verslaaf raak. Die deurwerking van die nuwe mens is in beginsel onweerstaanbaar as werk van die Heilige Gees. Op die weg van voortgaande vernuwing is daar egter steeds die terugval en voortgang. Op hierdie pad is in hierdie oorvleuelende bedeling van reeds en nog nie tog hoop. Vanuit hierdie hoop moet telkens weer op konkrete vlak nuut en emosioneel intelligent gedink en pastoraal begelei word, totdat die ou nuwe mens finaal nuutgemaak word. 


\section{Geraadpleegde bronne}

ADAMS, J.E. 1980. More than redemption. A theology of Christian counseling. Grand Rapids: Baker.

BAR-ON, R. 2001. Emotional intelligence and self-actualization. (In Ciarrochi, J., Forgas, J.P. \& Mayer, J.D. Emotional intelligence in everyday life. A scientific inquiry. Philadelphia: Psychology Press. p. 82-97.)

BAR-ON, R. \& PARKER, J.D.A., eds. 2000. The handbook of emotional intelligence. Theory, development and application at home, school, and in the workplace. San Francisco: Jossey-Bass.

BECHARA, A., TRANEL, D. \& DAMASIO, A.R. 2000. Poor judgment in spite of high intellect. Neurological evidence for emotional intelligence. (In Bar-on, R. \& Parker, J.D.A., eds. The handbook of emotional intelligence. San Francisco: Jossey-Bass. p. 192-214.)

BEDELL, J.R. \& LENNOX, S.S. 1997. Handbook for communication and problem-solving skills training. New York: Wiley.

BEST, E. 1998. A critical and exegetical commentary on Ephesians. Edinburgh: Clark.

BOYATZIS, R.E., GOLEMAN, D. \& RHEE, K.S. 2000. Clustering competence in emotional intelligence. (In Bar-On, R. \& Parker, J.D.A., eds. The handbook of emotional intelligence. San Francisco: Jossey-Bass. p. 343-362.)

BURNARD, P.B. 1992. Know yourself. Self-awareness activities for nurses. London: Scutari.

CAMPBELL-LANE, Y. 2003. Inner change: a pastoral-theological study. Potchefstroom: North-West University. (Ph.D. thesis.)

CARVER, C.S. \& SCHEIER, M.F. 1998. On the self-regulation of behavior. Cambridge: University Press.

CIARROCHI, J., FORGAS, J.P. \& MAYER, J.D., eds. 2001. Emotional intelligence in everyday life. A scientific inquiry. Philadelphia: Psycholoy Press.

COLLINS, J. \& COLLINS, M. 2001. Social skills training and the professional helper. New York: Wiley.

DREYER, Y. 2003. Beyond psychology: spirituality in Henri Nouwen's pastoral care. Hervormde Teologiese Studies, 59(3):715-733.

FERRARI, M. \& STERNBERG, R.J., eds 1998. Self-awareness. Its nature and development. New York: Guilford.

FLOOR, L. 1995. Efeziërs. Een in Christus. Kampen: Kok.

GOLEMAN, D. 1998. Working with emotional intelligence. London: Bloomsbury.

GOLEMAN, D., BOYATZIS, R. \& McKEE, A. 2002. Primal leadership. Realizing the power of emotional intelligence. Boston: Harvard Business School Press.

GOLEMAN, D. 1997. Emotional intelligence. New York: Bantam.

KRUGER, P.A. 2003. Emosies en die uitdrukking van emosies in die Ou Testament. Nederduits Gereformeerde Teologiese Tydskrif, 44(1 \& 2):89100.

LINCOLN, A.T. 1990. Ephesians. Dallas: Word Books.

LOPES, A.N.G. 1986. The new man in Paul. Potchefstroom: PU vir CHO. (Th.M. dissertation.)

LOTTER, G.A. 2004. Emosionele intelligensie en die predikant. Ongepubliseerde voordrag. Potchefstroom: Fakulteit Teologie, Noordwes-Universiteit. 
LOUW, D.J. 1999. A mature faith. Spiritual direction and anthropology in a theology of pastoral care and counseling. Leuven: Peeters.

MacDONALD, M.Y. 2000 Colossians and Ephesians. Collegeville: Liturgical.

MUDDIMAN, J. 2001. A commentary on the epistle to the Ephesians. London: Continuum.

NOUWEN, H.J.M. 1981. The way of the heart. New York: Ballantine.

O'BRIEN, P.T. 1999. The letter to the Ephesians. Leicester: Apollos.

POVINELLI, D.J. \& PRINCE, G.C. 1998. When self met other. (In Ferrari, M. \& Sternberg, R.J., eds. Self-awareness its nature and development. London: Guilford. p. 37-107.)

RIDDERBOS, H. 1979. Paul: an outline of his theology. Michigan: Eerdmans.

RIENECKER, F. 1980. A linguistic key to the Greek New Testament. Volume 2. Grand Rapids: Zondervan.

ROBERTS, J. 1991. The letter to the Ephesians. Goodwood: Lux Verbi.

ROGERS, C.R. 1951. Client centered therapy. Boston: Brown.

SALOVEY, P., MAYER, J.D. \& CARUSO, D. 2002. The positive psychology of emotional intelligence. (In Snyder, C.R. \& Lopez, S.J., eds. Handbook of positive psychology. Oxford: Oxford University Press. p. 159-171.)

SNYDER, C.R. \& LOPEZ, S.J., eds. 2002. Handbook of positive psychology. Oxford: Oxford University Press.

STOTT, J.R.W. 1999. The Bible speaks today. The message of Ephesians. God's new society. Leicester: Intervarsity.

TAYLOR, G.J. \& BAGBY, R.M. 2000. An overview of the alexithymia construct. (In Bar-on, R. \& Parker, J.D. The handbook of emotional intelligence. San Francisco: Jossey-Bass. p. 40-67.)

VAN JAARSVELD, P. 2003. Die hart van 'n wenner. Ontwikkel jou emosionele intelligensie. Wellington: Lux Verbi.BM.

VERMEULEN, S. 1999. EQ emotional intelligence for everyone. Rivonia: Zebra.

WOODMAN, L. 1973. Perspectives on self-awareness. Essays on human problems. Columbus: Ohio.

\section{Kernbegrippe:}

emosionele intelligensie: gedragwyse, selfbewussyn

kommunikasiewyse: hantering van woede

nuwe mens: die implikasies hiervan (Ef. 4:20-24)

\section{Key concepts:}

communicative ways: management of anger emotional intelligence: ways of behaviour, selfawareness "made new" in mind and spirit: the implications (Eph. 4:20-24) 
